\title{
Потемкина А.A. \\ Последствия недействительности сделок, направленных на вывод активов должника
}

Волгоградский государственный университет (Россия, Волгоград)

doi: $10.18411 / \mathrm{j}-06-2021-236$

\section{Аннотация}

В статье рассматриваются вопросы заключения недействительных сделок и причинения имущественного вреда кредиторам, а также раскрываются проблемы, последствия недействительности сделок. должник.

Ключевые слова: подозрительные сделки, недействительность сделки,

\section{Abstract}

The article discusses the issues of concluding invalid transactions and causing property damage to creditors, as well as reveals the problems, consequences of the invalidity of transactions.

Keywords: suspicious transactions, invalidity of the transaction, the debtor.

Сделка, которая совершена должником с целью причинить вред имущественным правам кредиторов, может быть признана арбитражным судом недействительной, в случае, если данная сделка была совершена в период, предшествующий трем годам до принятия заявления о признании должника банкротом или после принятия к производству указанного заявления, и в результате совершения этой сделки был причинен вред имущественным правам кредиторов, а также, если другая сторона сделки была осведомлена об указанной цели должника к моменту совершения сделки. Предполагается, что другая сторона была осведомлена, если она является заинтересованным лицом, либо если оназнала или должна была знать обнарушении баланса интересов кредиторов должника, либо о признаках неплатежеспособности или недостаточности имущества должника.

Если сделка была совершена должником в состоянии имущественного кризиса в отношении заинтересованного лица, то можно сказать о том, что одновременно являются доказаннымии неправомерная цель должника, и осведомленность контрагента об этой цели.

Среди специальных банкротных оснований оспаривания сделок можно выделить оспаривание преференциальных сделок и оспаривание подозрительные сделок (ст. 61.2 Ф3 «О несостоятельности (банкротстве)»). К последним можно относить сделки, которые совершены на нерыночных условиях, сделки, которые совершены в отсутствие фактического предоставления, которые являются нетипичными для должника сделки, сделки с неплатёжеспособными контрагентами.

Есть два вида подозрительных сделок: сделки с неравноценоценным представлением другой стороной и сделки с причинением имущественного вреда кредиторам.

Для квалификации сделки с неравноценностью встречного исполнения необходимо установить следующие факты: сделка должна быть совершена не ранее одного года до принятия заявления о признании должника банкротом, а также сама неравноценность встречного исполнения. При этом такая неравноценность встречного исполнения должна быть существенной.

Для того, чтобы квалифицировать сделку, в качестве совершенной должником с целью причинения вреда имущественным правам кредиторов, должен быть доказан вред имущественным правам кредиторов, а также осведомленность стороны о конечной цели заключаемой сделки. Подобная сделка должна заключаться в трехгодичный период до принятия заявления о признании должника банкротом. В 
таких случаях действует презумпция причинения вреда имущественным правам кредитора и презумпция знания другой стороны сделки о конечной цели причинить вред имущественным правам кредитора, если лицо уже признано заинтересованным.

Цель причинения имущественного вреда презюмируется, если на момент совершения сделки должник отвечал критериям неплатежеспособности, находился в состоянии имущественного кризиса, или условия данной сделки отличались от обычных и говорили о наличии цели причинения имущественного вреда. В качестве доказательств осведомленности контрагента можно считать публикации о введении процедур банкротства должника или наличие иных судебных разбирательств.

Последствия недействительности сделок несостоятельного должника, которые установлены Федеральным законом от 26.10.2002 г. № 127-Ф3 "О несостоятельности (банкротстве)", отражают суть и особенности таких сделок и выступают в качестве специальных. Указанные последствия не могут исключать реституционного характера обязательственных охранительных правоотношений, которые возникают в связи с применением таких последствий.

Применение последствий недействительности сделки подлежит осуществлению в рамках реституционных отношений. Основания для возникновения данных правоотношений - являются юридические факты: совершение недействительной сделки и осуществление исполнения по ней; в качестве содержания - совокупность субъективных реституционных прав и обязанностей.

Bce, что передано должником или иным лицом за счет средств должника или в счет исполнения какого-либо обязательства перед должником, а также все то, что изъято у должника по сделке, которая признана недействительной, возвращается в конкурсную массу. В случае невозможности возврата имущества в конкурсную массу в натуре приобретателем должна быть возмещена действительная стоимость этого имущества на момент его приобретения, а также убытки, которые вызваны последующим изменением стоимости имущества, согласноположению об обязательствах, которые возникают вследствие неосновательного обогащения. Кредиторы и иные лица, которым было передано имущество или перед которыми должник исполнял обязательства или обязанности по сделке, которая была признана судом недействительной, в случае возврата в конкурсную массу полученного по оспоренной сделке имущества, приобретают право требования к должнику.

Правоотношения, которые связаны с применением последствий недействительности сделок несостоятельного должника обладают относительным, обязательственным, охранительным и реституционным характером. Содержание таких правоотношений - это совокупность субъективных реституционных прав и обязанностей несостоятельного должника и его стороны по недействительной сделке. Законом о банкротстве, по сути, устанавливается специальная, "банкротная", реституция. Особенность "банкротной" реституции заключается в необходимости возврата в конкурсную массу имущества, полученного от должника по недействительной сделке и приобретением после этого возврата стороной права требования к должнику, которое подлежит включению в реестр требований кредиторов.

На основании вышеизложенного, можно сделать основные выводы.

1. Последствия недействительности сделки принято классифицироватьна общие, специальные и дополнительные. Общие последствия установлены правилом п. 2 ст. 167 ГК РФ, специальными выступают немного иные последствия, которые предусмотрены законом; дополнительными, которые применяются субсидиарно по отношению к общим либо специальным последствиям, возмещение реального ущерба и возмещение убытков.

2. Последствия недействительности сделок в делах о несостоятельности, которые установлены правилами ст. 61.6. Закона о банкротстве, отражают особенности подобных сделок и являются специальными. 
3. Правоотношения, которые сопряжены с применением последствий недействительности сделки, называют реституционными. Основания возникновения данных правоотношений исходят из юридического состава фактов совершения недействительной сделки и непосредственного осуществления исполнения по ней. Содержание таких правоотношений выступает совокупность субъективных реституционных прав и обязанностей сторон оспариваемой сделки.

4. Реституционные правоотношения можно определить в качестве относительных, обязательственных, охранительных гражданских правоотношений, которые возникают вследствие совершения недействительной сделки и осуществления исполнения по ней, а также сопряжены с применением последствий недействительности сделки.

5. Специальные последствия недействительности сделок в рамках дела о несостоятельности (банкротстве) не исключают реституционного характера обязательственных охранительных правоотношений, которые возникают в связи с применением этих последствий. Данные правоотношения обладают всеми элементами реституционного правоотношения. Содержание таких правоотношений включает в себя совокупность субъективных реституционных прав и обязанностей несостоятельного должника и его контрагента по недействительной сделке.

6. Последствия недействительности сделок несостоятельного должника определяют в качестве специальной, "банкротной", реституции, предполагающей с одной стороны обязанность контрагента должника возвратить полученное от должника в конкурсную массу, а с другой стороны - удовлетворение требований к должнику по возврату полученного по недействительной сделке в порядке и очередности, установленнойФЗ «О несостоятельности (банкротстве)».

$$
* * *
$$

1. Гражданский кодекс Российской Федерации (Часть первая): федеральный закон от 30 ноября 1994 г. № 51-Ф3 (в редакции от 08.12.2020) // Собрание законодательства Российской Федерации. 1994. - № 32. - Ст.3301;

2. О несостоятельности (банкротстве): Федеральный закон от 26.10.2002 № 127-Ф3 (ред. от 29.12.2014) // Российская газета. 02.11.2002, № 209-210.

3. Макаров И.А. К вопросу об оспаривании в рамках дела о несостоятельности (банкротстве)действий по уплате (взиманию) налогов и иных обязательных платежей // Закон. 2012. N 11. C.45-50.

4. Праскелова Д.В. Особенности применения последствий недействительности оспоримых сделок // Правовое государство: теория и практика. 2014. № 3 (37). С. 41-44.

5. Федчун, А. В. Право на оспаривание сделок наследодателя: поиск баланса интересов / А. В. Федчун // Правовая парадигма. - 2017. - Т. 16. - № 4. - С. 117-125

Пухалов И.А., Прохоров Д.Д.

\section{Проблемы законности посягательства на адвокатскую тайну}

Кубанский государственный аграрный университет им. И. Т. Трубилина (Россия, Краснодар)

doi: $10.18411 / \mathrm{j}-06-2021-237$

\section{Аннотация}

За разглашение сведений, составляющих адвокатскую тайну, адвокат может быть привлечен к дисциплинарной ответственности советом адвокатской палаты. Но 